\title{
PENGALAMAN KELUARGA MERAWAT LANSIA DENGAN TINGKAT KETERGANTUNGAN TINGGI DI RUMAH, KOTA MALANG, JAWA TIMUR: STUDI FENOMENOLOGI
}

\author{
Joko Wiyono*, Junaiti Sahar**, Wiwin Wiarsih**
}

\begin{abstract}
Abstrak
Penelitian fenomenologi deskriptif ini bertujuan mendapatkan gambaran arti dan makna pengalaman keluarga dalam merawat lansia dengan ketergantungan tinggi di rumah, di Kota Malang. Data dikumpulkan dari 8 anggota keluarga pemberi asuhan utama pada lansia di keluarga dan dianalisis dengan metode Colaizzi. Hasil penelitian menggambarkan alasan keluarga merawat lansia di rumah, alasan utama merawat, alasan penunjang merawat, kegiatan merawat, persepsi selama merawat, koping selama merawat, dukungan selama merawat, masalah selama merawat dan upaya selama merawat; perubahan dalam keluarga berupa perubahan peran, fungsi keluarga dan tugas keluarga; dan dampak pada pemberi asuhan informal; makna dari pengalaman merawat lansia yaitu perubahan sikap menjadi lebih sabar; dan sumber kebutuhan pelayanan kesehatan. Perawat keluarga perlu mempertimbangkan sumber daya keluarga dan dinamika budaya setempat. Penelitian selanjutnya dapat membandingkan atau mengetahui hubungan berbagai macam variabel yang muncul sebagai tema dalam penelitian ini.
\end{abstract}

Kata kunci: lansia ketergantungan tinggi, merawat, pengalaman keluarga.

\section{Abstract}

This descriptive phenomenology research was aimed to describe the meaning and essence of family experience in caring for high dependence elderly at home, in Malang City. The data was collected from 8 primary informal caregivers for elderly in family and analyzed by Collaizi's method. The result described family reason for nursing care for elderly at home, main reason in providing care, supporting reason for providing care; nursing activities, perception during providing care, coping, support, problem encountered and efforts during nursing care for elderly; change of family role, function, and task; attitude change to be more patience as the meaning of experience; and source of health service needs. Family nurses need to consider available family source and the local culture. Further research is also recommended to compare or identify relationship of various variables that occurred as themes in this present research.

Key words: family experience, high dependence elderly, nursing

\section{LATAR BELAKANG}

Proses menua adalah proses alami yang disertai adanya penurunan kondisi fisik, psikologis, dan sosial yang saling berinteraksi satu sama lain (Lueckenotte, 2000; Watson, 2003). Penurunanpenurunan tersebut memberikan dampak pada kemampuan lansia dalam melakukan aktifitas sehari-hari/ activity daily livings (ADL) yang memerlukan perhatian dan bantuan dari keluarga.

Kenaikan umur harapan hidup membawa dampak pertambahan jumlah lansia di Indonesia. Lansia di Indonesia cenderung tinggal bersama keluarga. Karakteristik keluarga Indonesia yang merupakan suatu kesatuan yang utuh, mempunyai semangat gotong royong, ikatan keluarga yang erat, keluarga besar (extended family), dan sangat menghormati orang tua menyebabkan keluarga tinggal bersama dan mengasuh lansia sampai akhir hayatnya (Effendy, 1998; Perkumpulan Keluarga Berencana Indonesia/PKBI, 2000).

Keluarga sebagai pemberi asuhan informal, dalam melaksanakan fungsi memberikan perawatan pada lansia melibatkan seluruh aspek yaitu fisik, psikologis, emosional, sosial, dan finansial. Berbagai dampak dapat timbul sebagai respon dari interaksi keluarga dengan lansia ketika pemberian asuhan (Friedman, 2003; Potter \& Perry, 2005).

Keluarga yang memandang pemberian asuhan 
kepada lansia merupakan suatu beban atau masalah, maka akan memiliki konsep negatif sebagai pemberi asuhan. Sebaliknya, jika keluarga memandang pemberian asuhan kepada lansia merupakan suatu kewajiban, kebanggaan, atau meningkatkan kepuasan, maka akan memiliki konsep positif sebagai pemberi asuhan (Hunt, 2003; Lueckenotte, 2000).

Pemahaman tentang keluarga sebagai pemberi asuhan sangat penting diketahui perawat karena partisipasi keluarga dalam perawatan lansia dibutuhkan untuk mencapai hasil yang optimal dari intervensi keperawatan. Keluarga sebagai pemberi asuhan dalam merawat lansia dengan ketergantungan tinggi di rumah, dalam menjalankan perannya harus memiliki pengetahuan yang baik tentang perawatan lansia (Gaugler et al., 2002 dalam Sebern, 2005; Tyson, 1999).

Fenomena pemberian asuhan pada lansia di rumah sangat penting untuk dipahami guna merencanakan dan memberikan pelayanan lansia khususnya kebutuhan pemberi asuhan. Kebutuhan pemberi asuhan menjadi perhatian utama karena dalam merawat lansia biasanya memerlukan waktu yang panjang dan melibatkan seluruh aspek kehidupan pemberi asuhan. Penelitian ini bertujuan mendapatkan gambaran tentang arti dan makna pengalaman keluarga dalam merawat lansia dengan tingkat ketergantungan tinggi di rumah, di kota Malang.

\section{METODE PENELITIAN}

Penelitian ini menggunakan metode fenomenologi deskriptif dalam memahami arti dan makna pengalaman keluarga merawat lansia dengan ketergantungan tinggi di rumah. Fokus penelitian ini adalah penemuan fakta suatu fenomena pengalaman keluarga merawat lansia berdasarkan perspektif informan. Tujuan menggunakan pendekatan fenomenologi deskriptif adalah mengeksplorasi fenomena pengalaman keluarga dalam merawat lansia di rumah.
Informan berjumlah 8 orang yang diseleksi menggunakan teknik sampling purposive dengan jenis convenience sampling. Pengambilan data dilakukan di Desa Sawojajar, wilayah Puskesmas Gribig, Kota Malang, Jawa Timur pada bulan Mei 2007. Pertimbangan etik yang digunakan dalam penelitian ini meliputi self determination, privacy, anonimity, confidentiality, dan protection from discomfort.

Metode pengumpulan data yang digunakan dalam penelitian ini adalah wawancara mendalam dengan bentuk pertanyaan yang diajukan selama proses wawancara adalah semi terstruktur dan pertanyaan terbuka. Alat pengumpulan data dalam penelitian ini adalah peneliti sendiri, pedoman wawancara, catatan lapangan, dan tape recorder.

Proses analisis dalam penelitian ini menggunakan langkah-langkah dari Colaizzi (1978, dalam Streubert \& Carpenter, 1999). Langkah ini diawali dengan membaca transkrip berupa deskripsi informasi dari informan secara berulang-ulang sampai memperoleh pemahaman yang sama dengan pandangan informan. Peneliti selanjutnya mengidentifikasi kata kunci dengan memahami setiap kalimat yang terdapat dalam transkrip dan memberi tanda berupa garis bawah pada kata-kata yang merupakan kata kunci dari masing-masing pemahaman arti. Langkah berikutnya yaitu mengambil arti dari kata kunci yang merujuk pada pernyataan informan yang signifikan untuk merumuskan kategori. Kategori yang serumpun dikelompokkan ke dalam sub-sub tema. Kemudian, dengan perlakuan yang sama subsub tema serumpun dikelompokkan ke dalam sub tema dan sub tema yang serumpun diorganisasikan ke dalam tema. Selanjutnya, peneliti menunjukkan kisi-kisi tema pada masing-masing informan untuk memperoleh validasi. Peneliti pada akhirnya mengintegrasikan semua hasil penelitian ke dalam suatu narasi yang menarik dan mendalam sesuai dengan topik penelitian.

\section{HASIL PENELITIAN}

Peneliti mengidentifikasi 13 tema sebagai 
hasil penelitian ini, selanjutnya tema-tema tersebut diuraikan berdasarkan tujuan khusus penelitian.

\section{Alasan keluarga merawat lansia dengan tingkat ketergantungan tinggi di rumah}

\section{Tema 1: Alasan keluarga merawat lansia di rumah}

Alasan utama menentukan keputusan merawat lansia di rumah. Alasan ini meliputi:

a) kepuasan personal yang ditunjukkan dalam pernyataan berikut ini.

“...merawat di rumah itu lebih leluasa...” (P1)

“...biar dekat yang merawat tidak repot...”(P6)

b) ekonomi keluarga yang ditunjukkan pernyataan:

“...gak ada biaya.... Kalau di rumah kan biaya tidak terlalu besar, apa adanya..." (P3)

c) perkembangan kondisi kesehatan lansia yang ditunjukkan dengan pernyataan:

“...kalau kita bawa kemana-mana itu...nol sudah....” (P2)

“...model-modelnya kan tidak bisa sembuh.” (P5)

e) kondisi kesehatan lansia yang ditunjukkan:

“...sudah tua ...ndak bisa jalan...”(P7)

Alasan penunjang merawat lansia di rumah untuk menjaga kestabilan keluarga yang ditunjukkan dalam pernyataan:

“...tidak merepotkan, masih bisa ngerjakan pekerjaan rumah.” (P1)

“...bisa disambi-sambi, kan saya menjaga toko dan anak.” (P3)

"Kalau di rumah ya bisa mengerjakan pekerjaan yang di rumah sambil merawat...” (P4)

“...biar selalu dekat...” (P8)

“...memasak bisa nengok...santai bisa nengok... perhatian lebih...pikiran tenang...” (P6)

“...biaya juga ...kalau di rumah paling-paling beli obat gitu tok...” (P4)

“...kalau bisa di rawat di rumah kenapa harus dirawat di rumah sakit...” (P1)

Alasan lainnya yaitu keterbatasan sistem pendukung yang ditunjukkan:

“...keluarganya cuman tinggal saya dan adik tok...” (P3)

“...ya saya sendiri ...anak-anak sudah rumah tangga sendiri ...” (P2)

“...hanya saya yang mau merawat, pak ...” (P7)

\section{Tema 2: Alasan utama merawat lansia}

Alasan utama merawat lansia karena kewajiban keluarga terhadap lansia yang terdiri dari tanggung jawab antar generasi yang ditunjukkan dalam pernyataan:

“...kewajiban kita anaknya untuk merawat..." (P8)

“...anak kan harus merawat orang tua...” (P3)

“...kalau nggak anaknya siapa lagi yang merawat..."(P7)

“...itu kan orang tua sendiri ...” (P5)

“...tanggung jawab sebagai cucu ...” (P6)

dan tanggung jawab moral yang ditunjukkan:

"Saya punya perasaan takut berdosa kalau saya tidak merawat ...” (P1)

“...bakti anak kepada orang tua ...” (P6) (P1)

“Waktu kecil kan saya juga dirawat mama..."

"Jadi sejarah pertama itu saya ingat terus... pertama ketemu dulu...walaupun saya merawat sendiri tetap saya rawat, pak." (P2)

\section{Tema 3: Alasan penunjang merawat lansia}

Alasan penunjang merawat lansia karena keterbatasan fisik lansia yang tidak mampu mandiri, risiko masalah kesehatan lansia jika tidak dirawat, kedekatan emosi keluarga dengan lansia, tugas berbasis jender sebagai anak perempuan di rumah. 
2. Respon keluarga selama merawat lansia dengan tingkat ketergantungan tinggi di rumah

\section{Tema 4: Kegiatan merawat lansia}

Kegiatan merawat lansia dilakukan untuk memenuhi kebutuhan dasar yaitu kebutuhan fisiologi, sosialisasi, rekreasi, dan spiritual lansia.

\section{Tema 5: Persepsi selama merawat}

Persepsi selama merawat terdiri dari perasaan selama merawat dan nilai dalam merawat. Nilai dalam merawat lansia terjadi karena merawat lansia merupakan suatu kebanggaan. Variasi perasaan yang muncul selama merawat lansia berupa senang, tidak senang, dan menerima yang ditunjukkan dalam pernyataan berikut:

“...kalau bisa merawat orang tua ...melayani orang tua itu kan juga senang...” (P1)

“...seneng bisa selalu dekat ...ikhlas...seperti merawat anak saya sendiri.” (P6)

“...saya rawat bertahun-tahun masih diberi umur panjang...” (P5)

“...sakitnya sudah lama...sudah tua lagi....” (P1)

“...sepertinya tidak diperhatikan padahal yang diminta sudah disiapkan, selalu dituruti gitu." (P5)

“...sudah hadiah dari yang Maha Kuasa.” (P2)

Tema 6: Koping selama merawat

Mekanisme koping adaptif dilakukan dengan mencari pengganti, memberikan perhatian, bergantian dalam merawat dengan anggota keluarga lain, dan aktifitas pengalihan. Mekanisme koping maladaptif dilakukan dengan pengabaian.

\section{Tema 7: Dukungan selama merawat}

Dukungan selama merawat dari internal meliputi sumber dukungan, bentuk dukungan, dan harapan dukungan. Harapan dukungan dari internal dapat berupa membantu aktifitas merawat, kunjungan, bantuan pemikiran, dan bantuan dana. Harapan dukungan dari eksternal dapat berupa pengertian lingkungan masyarakat, kebebasan berpartisipasi, membantu aktifitas merawat, dan informasi dari lingkungan.

\section{Tema 8: Masalah selama merawat}

Masalah selama merawat terjadi karena keterbatasan keluarga dan dilema bersikap dalam merawat. Keterbatasan keluarga berupa keterbatasan sumber pendukung. Dilema bersikap dalam merawat dapat terjadi karena variasi perasaan antara menerima dan menolak.

\section{Tema 9: Upaya selama merawat}

Upaya yang dilakukan selama merawat lansia adalah mengoptimalkan kemampuan yang ada, berdoa, musyawarah atau diskusi, dan penanganan melalui terapi alternatif.

\section{Dampak terhadap keluarga selama merawat lansia dengan tingkat ketergantungan tinggi}

\section{Tema 10: Perubahan dalam keluarga}

Perubahan dalam keluarga yang dikemukakan informan terdiri dari perubahan peran, fungsi, dan tugas keluarga. Dampak perubahan ini ditunjukkan pada pernyataan berikut:

“...mengerjakan kegiatan rumah tangga, membuka toko di rumah sejak mama sakit...karena sebelumnya kerja di luar.” (P1)

“...terutama ini sudah ndak bisa apa-apa... umpama saya tinggal kerja sudah berantakan, satu hari itu saja saya tinggal kerja sudah...” (P7)

“...karena merawat itu anaksering tidakterurus...” (P5)

"Dulu rutin periksa, pak, tapi sudah satu tahun ini pengobatan dihentikan." (P1)

\section{Tema 11: Dampak pada pemberi asuhan}

Dampak pada pemberi asuhan meliputi hassles, strain, dan burden yang dikelompokkan dalam dampak fisik, psikologis, sosial, dan finansial. Ini ditunjukkan dalam pernyatan berikut:

"Lucunya ...kayak anak kecil...mintanya anehaneh..." (P5)

"Gimana ya...nggak sabaran gitu...darah tinggi..." (P7)

“Orang kerja kan ya capek, saya itu ya bagaimana ya..." (P2) 
“...masalahnya kalau mintanya sekarang ya sekarang...” (P4)

“...masalahnya kalau mintanya sekarang ya sekarang...” (P5)

"Mau dibawa kemana, wong dirawat di rumah semampunya...seadanya...” (P3)

\section{Makna dari pengalaman merawat lansia dengan tingkat ketergantungan tinggi di rumah}

\section{Tema 12: Perubahan sikap}

Perubahan sikap dalam keluarga yang dikemukakan informan adalah perubahan sikap positif yang muncul yaitu menjadi lebih sabar yang ditunjukkan dengan pernyataan:

"Saya justru menjadi lebih sabar..." (P1)

“...sudah saya serahkan yang Maha Kuasa ...saya terima aja.”( $\mathrm{P} 2)$

\section{Kebutuhan pelayanan kesehatan yang diperlukan keluarga dalam merawat lansia Tema 13: Kebutuhan sumber pelayanan kesehatan}

Kebutuhan sumber pelayanan kesehatan dalam merawat lansia di rumah meliputi petugas kesehatan dan biaya perawatan. Kebutuhan sumber pelayanan kesehatan dari petugas kesehatan terdiri dari jenis layanan, jenis kegiatan, dan jenis aktifitas. Jenis layanan dari petugas kesehatan dapat berupa informasi kesehatan dari aspek penyampaian informasi: metode, jenis kebutuhan informasi, dan pemeriksaan kesehatan.

Ketersediaan pelayanan sesuai kebutuhan ditunjukkan dengan pernyataan berikut:

"Memberikan penjelasan-penjelasan ...apa yang terbaik dilakukan.” (P1)

"Pemeriksaan kan minimal tahu perkembangan ..." (P5)

"Petugasnya datang, pak...kan bisa melihat kondisi...” (P3)

“...diberitahu bagaimana caranya merawat yang
baik...”(P4)

“...tapi ya kalau berobat yang mahal kan tidak mampu, jadi kalau bisa yang untuk orang-orang seperti kita diperhatikan." (P7)

\section{PEMBAHASAN}

\section{Alasan keluarga merawat lansia dengan ketergantungan tinggi di rumah}

Alasan utama merawat lansia di rumah meliputi kepuasan personal,ekonomi keluarga, perkembangan kondisi kesehatan lansia, dan kondisi kesehatan lansia. Alasan penunjang termasuk menjaga kestabilan keluarga. Alasan lainnya yaitu keterbatasan sistem pendukung.

Hal ini sesuai dengan pernyataan bahwa perawatan lansia bersifat jangka panjang dan melibatkan seluruh aspek fisik, psikologis, emosional, dan finansial bagi keluarga (Friedman, 2003; Potter \& Perry, 2005). Selain itu sesuai dengan karakteristik keluarga di Indonesia yang mempunyai ikatan erat, keluarga besar, dan sangat menghormati orang tua menyebabkan keluarga tinggal bersama dan mengasuh lansia sampai akhir hayatnya (Effendy, 1998).

Alasan keluarga merawat lansia dalam hal untuk menjaga kestabilan keluarga berbeda dengan penelitian yang dilakukan Conell (2003). Conell menggambarkan bahwa merawat lansia di rumah menyebabkan terjadinya ketidakseimbangan peran pemberi asuhan. Hal ini dimungkinkan terjadi karena budaya yang berbeda dimana pemberi asuhan di Indonesia utamanya di daerah pedesaan yang cenderung tinggal di rumah dan tidak mempunyai kesibukan lain di luar rumah sehingga peran pemberi asuhan dapat dilakukan dengan baik dengan merawat lansia di rumah.

Alasan merawat lansia dianggap sebagai kewajiban. Hasil penelitian Center for Population and Policy Studies Universitas Gadjah Mada/UGM (1999) juga menggambarkan bahwa merawat orang tua merupakan suatu kewajiban dan perwujudan bakti anak. Hal ini dapat terjadi karena penelitian dilakukan di daerah yang mempunyai karakteristik 
dan budaya hampir sama.

Variasi pemberi asuhan didasari oleh berbagai macam alasan utama merawat lansia, yaitu tanggung jawab antar generasi dan tanggung jawab moral. Hal ini juga sesuai dengan pendapat Day (2000) bahwa pemberi asuhan informal dalam melakukan perawatan didasarkan pada hubungan kekeluargaan, teman, tetangga, atau anggota kelompok ibadah yang tidak dibayar karena kecintaan, hormat, kewajiban, atau kesetiakawanan kepada orang yang tidak mampu merawat diri.

Kewajiban merawat orang tua juga terjadi karena merupakan tanggung jawab moral anak terhadap orang tua. Hal ini sesuai dengan karakteristik keluarga di Indonesia. Demikian juga penelitian lain yang dilakukan oleh Martire di Pittsburgh (2006) menunjukkan bahwa anak dewasa yang merawat orang tuanya melaporkan bahwa mereka dapat membayar kembali asuhan yang orang tua berikan pada saat mereka masih kecil.

Pemberi asuhan kepada lansia dapat dilakukan oleh seluruh anggota keluarga tetapi wanita secara tradisional diasumsikan dan diterima mempunyai peran sebagai pemberi asuhan secara alamiah. Penelitian yang dilakukan Center for Population and Policy Studies UGM (1999) mengambarkan bahwa lansia menggantungkan hidupnya terutama pada anak perempuan terdekat. Kedua penelitian diatas mempunyai kesamaan dalam memandang anak perempuan sebagai pemberi asuhan utama pada orang tuanya.

\section{Respon keluarga selama merawat lansia dengan tingkat ketergantungan tinggi di rumah}

Kegiatan merawat lansia ditujukan untuk memenuhi kebutuhan dasar manusia. Variasi perasaan muncul selama merawat lansia berupa senang, tidak senang, dan menerima. Penelitian lain yang dilakukan Martire (2006) juga menggambarkan terjadinya variasi perasaan selama merawat lansia di rumah, yaitu perasaan sedih, tidak punya harapan ke depan, dan kesulitan konsentrasi.
Ketergantungan lansia yang tinggi meningkatkan risiko kekerasan dan penelantaran, terutama jika anggota keluarga yang merawat lansia tidak mempunyai mekanisme koping yang baik. Mekanisme koping adaptif yang dapat dilakukan keluarga dari sumber internal adalah fleksibilitas peran dan meningkatkan kohesivitas (Friedman, 2003; Sally, 2001; Stanhope \& Lancaster, 2002). Dukungan terhadap keluarga yang merawat lansia dapat berasal dari internal dan eksternal keluarga. Penelitian lain yang dilakukan Stewart et al. (1998) mengambarkan bahwa dalam dukungan sosial dari keluarga yang juga merawat lansia berupa informasi dan strategi koping yang didasarkan pada pengetahuan pengalaman mereka serta dukungan emosional.

\section{Dampak terhadap keluarga selama merawat lansia dengan tingkat ketergantungan tinggi di rumah}

Perubahan peran, fungsi, dan tugas keluarga merupakan dinamika keluarga yang merawat lansia. Perubahan peran ini dapat berpengaruh baik langsung maupun tidak langsung pada fungsi ekonomi keluarga.

Dampak pada pemberi asuhan akibat merawat lansia dapat berupa hassles, strain, dan burden. Hasil penelitian ini menggambarkan bahwa dampak pada pemberi asuhan akibat merawat lansia berupa hassles, strain, dan burden. Hal ini sesuai dengan penelitian lain yang dilakukan oleh Stommel et al. (1990) yang menggambarkan bahwa dampak pemberi asuhan kepada lansia terhadap finansial, perasaan yang terbuang, dampak pada jadwal kerja, dampak terhadap kesehatan, dan perasaan terisolasi.

\section{Makna dari pengalaman merawat lansia dengan tingkat ketergantungan tinggi di rumah}

Makna dari pengalaman merawat lansia dengan tingkat ketergantungan tinggi di rumah adalah perubahan sikap dalam hubungan dengan lansia, yaitu menjadi lebih sabar. Penelitian Vellone et al. (2002) sebaliknya mengungkapkan bahwa perubahan sikap dalam hubungan dengan klien dan anggota keluarga lain adalah perubahan sikap 
negatif. Hal ini dapat terjadi karena pengaruh budaya setempat.

\section{Kebutuhan pelayanan kesehatan yang diperlukan keluarga dalam merawat lansia dengan tingkat ketergantungan tinggi di rumah}

Kebutuhan pelayanan keperawatan terhadap keluarga yang merawat lansia di rumah adalah ketersediaan pelayanan sesuai kebutuhan. Ini sesuai dengan pendapat Rice (2001) bahwa ketersediaan pelayanan keperawatan terhadap keluarga harus diimbangi dengan kemampuan keluarga dalam memanfaatkan pelayanan tersebut, baik dalam hal jarak, waktu, dan finansial. Hal sebaliknya terjadi di Indonesia. Wakil Ketua Komisi IX DPR 20042009, Aisyah Salekan mengatakan masyarakat pemilik Askeskin masih mengalami kesulitan memperoleh fasilitas perawatan kesehatan gratis karena hambatan pada administrasi yang lambat akibat jumlah petugas sangat minim serta jarak terlalu jauh. Fasilitas pelayanan kesehatan lansia bagi keluarga yang merawat lansia di rumah, berupa tempat fasilitas pelayanan penunjang maupun kunjungan rumah belum tersedia, khususnya di daerah-daerah seperti Malang.

\section{KESIMPULAN}

Alasan keluarga merawat lansia di rumah disebabkan oleh ekonomi keluarga, kepuasan personal, kondisi kesehatan lansia, menjaga kestabilan keluarga, dan keterbatasan sumber pendukung. Keluarga dalam merawat lansia merupakan bentuk kewajiban sebagai tanggung jawab antar generasi dan tanggung jawab moral yang dilakukan oleh keluarga inti serta anggota keluarga yang mempunyai kedekatan emosional.

Kegiatan merawat lansia dengan tingkat ketergantungan tinggi oleh keluarga untuk memenuhi kebutuhan dasar manusia. Mekanisme koping maladaptif pengabaian berpotensi timbulnya abuse dan neglect pada lansia. Perubahan peran, fungsi keluarga dan tugas keluarga dapat terjadi selama merawat lansia. Dampak merawat lansia pada pemberi asuhan berupa hassles, strain, dan burden yang terjadi pada fisik, psikologis, sosial, dan finansial.

Makna dari pengalaman keluarga merawat lansia dengan tingkat ketergantungan tinggi di rumah adalah perubahan sikap positif, yaitu menjadi lebih sabar. Keluarga dalam memaknai pengalaman merawat lansia di rumah berbeda antara daerah satu dengan lain yang dipengaruhi oleh budaya daerah setempat.

Perawat dalam bekerja dengan keluarga yang merawat lansia di rumah perlu mempertimbangkan kemampuan keuangan keluarga; keyakinan dan persepsi keluarga tentang perawatan terhadap lansia; tingkat keparahan masalah kesehatan lansia untuk menentukan tempat perawatan; dan pemberi asuhan diprioritaskan dari keluarga inti atau yang mempunyai kedekatan emosional yang tinggi dengan lansia. Perawat dapat menggunakan dukungan sosial dan emosional, yaitu keluargakeluarga yang mempunyai pengalaman merawat lansia di rumah untuk memberikan dukungan terhadap keluarga yang merawat lansia di rumah untuk memperoleh informasi tentang pengalaman merawat lansia.

Peneliti menyarankan adanya jaminan pelayanan kesehatan masyarakat khusus lansia untuk memperpendek alur administrasi serta penyediaan transportasi ke pelayanan kesehatan. Program lansia di Puskemas perlu dikembangkan dengan pengadaan program pendampingan keluarga khususnya yang merawat lansia dengan tingkat ketergantungan tinggi di rumah.

Penelitian kuantitatif selanjutnya dapat dilakukan dengan membandingkan atau mengetahui lebih dalam hubungan variabel-variabel yang tergambar dalam tema-tema dalam penelitian ini. Penelitian selanjutnya juga dapat dilakukan dengan topik yang sama di daerah lain sehingga diperoleh pemahaman yang lebih kaya yang diperoleh dari berbagai pengalaman keluarga dari berbagai daerah di Indonesia (ENT, MD).

* Staf Akademik Keperawatan Komunitas Poltekkes Depkes Malang

** Staf Akademik Keperawatan Komunitas FIK 
UI

\section{KEPUSTAKAAN}

Center for Population and Policy Studies Gadjah Mada University di Yogyakarta (1999). Alternatif kebijakan terhadap lansia. http:// www.cpps.or.id, diperoleh 10 Januari 2007.

Connell, P.J. (2003). A phenomenological study of the lived of experiences of adult caregiving daugthers and the elderly mothers. http:// proquest.umi.com/pqdweb diperoleh 10 Januari 2007.

Day, T. (2000). About Caregiving. http://www. ericdigest s.org/pre-9219/family.htm diperoleh 29 Maret 2007.

Effendy, N. (1998). Dasar-dasar keperawatan kesehatan masyarakat. Jakarta: EGC.

Martire, L. (2006). Depression in family caregivers. http://www.wpic.pitt.edu/research /depr/care giver.htm, diperoleh 29 Maret 2007.

Friedman, M.M. (2003). Family nursing: Research, theory \& practice. ( $\left.5^{\text {th }} \mathrm{ed}\right)$. Connecticut: Appleton \& Lange.

Hunt, C.K. (2003). Conceps in caregiver research. Journal of Nursing Scholarship, 35, (1), 2830.

Lueckenotte, A.G. (2000). Gerontologic nursing. Philadelphia: Mosby-Year Book, Inc.

PKBI Pusat. (2000). Perkumpulan Keluarga Berencana Indonesia.

Potter, P.A. \& Perry, A.G. (1997). Fundamental of nursing: Concepts, process, and practice.
Philadelphia: Lippincott.

Rice, R. (2001). Home care nursing practice. St. Louis: Mosby Company.

Sally, S.S. (2001). Introduction gerontological nursing. Philadelphia: Lippincott.

Sebern, M. (2005). Shared care, elder family member skills used to manage burden. Journal of Advanced Nursing, 52 (2), 170-171.

Stanhope, M. \& Lancaster, J. (2000). Community health nursing: Promoting health of aggregates, families, and individuals. (5 $\left.5^{\text {th }} \mathrm{ed}\right)$. St. Louis: Mosby Year Book Inc.

Stewart, et al. (1998). Peer visitor support for family caregivers of seniors with stroke. Canadian Journal of Nursing Research, 30 (2), 87-117.

Stommel, et al. (1990). Caregiver. http://www. gwu.edu / cicd /toolkit/caregive.htm, diperoleh 4 Maret 2007.

Streuebert, H.J., \& Carpenter, D.R. (1999). Qualitative research in nursing advancing humanistic imperative. ( $\left.2^{\text {nd }} \mathrm{ed}\right)$. Philadelphia: Lippincott.

Tyson, S. R. (1999). Gerontological nursing care. Philadelphia: WB Saunders Company.

Vellone, et al. (2002). The experience of Italians caring for family member with Alzheimer's disease. Journal of Nursing Scholarship, 34 (4), 323-329.

Watson, R. (2003). Perawatan pada lansia. Jakarta:

Ketika kita menjadi tua, waktu akan membuat kita dikelilingi oleh orang-orang yang mencintai kita, sebagai ganti dari orang-orang yang kita cintai.

(J. Petit Senn)

Kita tidak bisa menjadi bijaksana dengan kebijaksanaan orang lain, tapi kita bisa berpengetahuan dengan pengetahuan orang lain. 